\title{
HISTORY OF ISLAMIC LAW ON EARTH MELAYU LANCANG KUNING RIAU-KEPRI
}

\author{
Nurhadi \\ Islamic College (STAI) Al-Azhar Pekanbaru Riau \\ alhadijurnal@gmail.com ; alhadicentre@yahoo.co.id
}

\begin{abstract}
Codification and cultural transformation in the Riau Malay region from a local religion to the Islamic religious system, complete with various forms of embodiment of all forms of culture. Revolution and religious reform in Riau Malay society which gave rise to cultural transformation were due to several inherent factors or other factors which were later strongly associated with Islam. Islam when it has to be actualized in culture has presented its face in harmony with the culture of culture in an area, and in the regional diversity of Islamic culture there is still a place for local Islamic culture. However, all cultural diversity is united by spirit and a sacred form of tradition that comes from tawhid. Riau Malay Culture is one of the forms of Islamic culture that has many supporters. Islamic values are clearly seen in various aspects of Riau Malay culture. Malays make Islam the spirit or core of their culture. The history of the entry of Islam, Islamic law, codification and compilation of Islamic law on the yellow Malay land of Riau Kepri tend to be modest, without any resistance mentally, socially, culturally and faithfully. This has led to the Trem that Malays are synonymous with Islam, especially Malay Riau.
\end{abstract}

Keywords: Islam, Integration, Codification, Compilation with Malay Culture

\section{INTRODUCTION}

The religion of Islam brought by the Prophet Muhammad, in the 7th century $\mathrm{AD}$, created an extraordinary driving force, which had been experienced by mankind. Islam is a giant movement that has traveled throughout the ages in its growth and development. The spread of Islam in Riau, viewed from a historical and geographical perspective through two roads, namely foreign trade and trade between regions. ${ }^{1}$

${ }^{1}$ Kadir, Abdul. (2010). History of the Entry of Islam in Riau. Pekanbaru: Indonesian National Library, p. 23; see also Divine, Afdhal. (2013). "Early Entry of Islam into Riau", afdhalilabi.blogspot.com, (12-03-2013), http://afdhalilahi.blogspot.com/2013/03/awal-masuknya-islam-ke-riau.html, accessed 11 July 2019. 
The Riau region which is located at the edge of the Strait of Malacca has been in the middle of the Malacca kingdom since the first century AD. ${ }^{2}$ The entry of Islam in this area is inseparable when relations with other countries begin. The arrival of Arab, Persian or Indian traders directly to this area. In the mid-XIII century, the Abbasid dynasty experienced a collapse and the Islamic center moved to Egypt, Morocco, and Persia which were directly related to Riau. ${ }^{3}$ These are the ones who brought Islam to Riau and in some areas of Riau namely: Kuntu / Kampar, Rokan, Kuantan, Gasib, Tapung and other areas in Riau. ${ }^{4}$

After the entry of Islam in Riau, of course the ups and downs of the development of Islam were also influential, because there were other parties who interfered in regulating the order of life of the Malay Malay Muslims of Riau, from invaders, power struggles and civil war between other Malay keslthanan. Therefore in this paper, the discussion will be directed with regard to Islamic history, namely:

1. How is the History of the Entry of Islam into Riau the Yellow Lancing Earth?

2. What is the History of Islamic Law in Lancang Kuning Riau-Riau Islands?

3. What is the Process of Codifying Islamic Law with Riau Malay Culture on Yellow Lancang Earth?

4. What are Riau Malay Muslims in Applying the Compilation of Islamic Law in Lancang Kuning Malay Earth?

${ }^{2}$ Wikipedia. (2019). "Malay Riau", wikipedia.org, http://id.wikipedia.org/wiki/Melayu_Riau, accessed July 11, 2019.

${ }^{3}$ Lutfi, Muchtar, Soewardi MS and Wan Ghalib, et.al. (Editor). (2011). History of Riau. Pekanbaru: Local Government Tk. I Riau, hm. 121

${ }^{4}$ Safitri, Mustika., Nuraini Asyidah Urpiah, Siti Amanah, Tri Wijayanti and Fikri Aulia. (2014). "The spread of Islam in Riau", a paper on the history of Southeast Asian Islam, the Miftahul 'Ulum Tanjungpinang Islamic College, document. Tips, http://dokumen.tips/documents/makalahpenyebaran-islam-di-riau.html, accessed July 11, 2019. 


\section{DISCUSSION}

\section{History of the Entry of Islam in Bumi Melayu Lancang Kuning Riau-Riau Islands}

In the historical record behind the entry of Islam into Riau as authentic evidence while ensuring the historical truth can be reviewed in three theories, namely: ${ }^{5}$

1. Theory from India

Discovered by Snouck Hurgronje: "As if some Indians embraced Islam, Muslims from India also took traffic and emigration in the archipelago, and they were the ones who put Islam in the archipelago". Then this opinion became popular and some Orientalists agreed on it, R.O. Winstedt, B. Harrison etc. The strength of Islamic theory only spread around the 13th century AD according to Snouck. ${ }^{6}$ Then the reason for confirming this theory is:

a. The initial gravestones found in Malay have been imported from Kambay (Kembayat) Gujerat.

b. The important role played by Gujerat traders in the Malay Archipelago and its impression of the spread of Islam.

c. The Malay Malay tradition is more like the Indian Islamic tradition.

d. Records of Marco Polo and Ibn Batutah who had visited the Malay Realm around the 13th and 14 th centuries AD. ${ }^{7}$

e. The discovery of the tomb of Sultan malik al-Salleh, the government of Pasai referred to in Malay History and Hikayat Raja-Raja Pasai as Government I in the Malay Archipelago. ${ }^{8}$

5Yhiiie. (2012). "History of the Entry of Islam in Riau", Yhiïe.Wordpress.Com, (11-29-2012), https://yhiiie.wordpress.com/2012/11/29/sejarah-masuknya-islam-di-riau/, accessed July 11, 2019.

${ }^{6}$ Weaknesses of this theory Snouck are: 1 . Recent studies - relations between the Malay and Arabic realms before the birth of Islam again. It is not right to say that the tombstone, which is found to resemble India, became Islam from India. 2. It is not only Indian traders who trade in the Malay Realm but also from other places such as China. 3. Arab traders who go to Canton also stop at Alam Melayu at least to get supplies or wait for the appropriate wind to continue their meraka voyage and this is the time they use to trade. Literary traditions began to develop long after Islam had long stepped on and expanded widely in India.

${ }^{7}$ Bertahta, Raja Tak . (2015). "History of Riau Malay Mainland and the Ocean", byuonx.blogspot.co.id, (03-23-2015), http://byuonx.blogspot.co.id/2015/03/sejarah-melayu-riaudaratan-dan -link.html, accessed July 11, 2019.

${ }^{8}$ Yhiiie. (2012). "History of the Entry of Islam in Riau". 
2. Theory from China

Prof.S.Q. Fatimi said the massive displacement of Muslims from Canton 876 (or 878) due to the rebellion that took place and resulted in casualties of up to 100,000-150,000 Muslims led them to go to Alam Melayu which among them according to S. Naquib to Kedah and Palembang. ' In addition, to Champa, Brunei, the east coast of T. Melayu (Patani, Kelantan, T'ganu and Pahang) and East Java. Evidence from Sheikh Abdul Qadir's tombstone in Langgar, Kedah, a stone with the words Phan-rang in Cambodia, Pahang tombstones and a stone that says Terenggganu 1303M. This Chinese influence is evidenced in the form of mosques in Malacca and Java such as the Pagoda. ${ }^{10}$ The evidence presented is quite convincing but does not mean Islam only at that time was only introduced in the Malay Realm because there had been an Islamic placement at the beginning of the Date, especially in northern Sumatra. ${ }^{11}$

3. Theory of Arab Land

This theory received a lot of support in the present, as proof of the interlacing is: ${ }^{12}$

a. Hamka: there is evidence that the Arabs had sailed to Indonesia before the birth of the Prophet Muhammad to buy spices hundred and camphor which were only found in Sumatra. The map / location of Alam Melayu has long been in the mind of the Arabs.

b. 7M Islam arrived in Sumatra when Muawiyah bin Abi Sofyan sent an envoy to the King of Srivijaya. Likewise, Umar bin Abd Azis has intensified da'wah and commerce in the Malay Realm.

\footnotetext{
${ }^{9}$ Ferrand, Gabriel. (1922). "L’Empire Sumatranais de Crivijaya, Imprimerie Nationale, Paris", "Textes Chinois".

${ }^{10}$ Sunanto, Musyrifah. (2015). History of Indonesian Islamic Civilization. Jakarta: PT Raja Grafindo Persada, pp. 17-18

11Perlis. (2019). "Islam in the Malay Realm", www.perlis.uitm.edu.my, http:/ / www.perlis.uitm.edu.my/cituimages/stories/gallery202\%20\%20islam $\% 20 \mathrm{di} \% 20 \mathrm{alam} \% 20$ mela yu\%20\%5Bpp \% 5D.pdf, accessed July 11, 2019.

12Pinang, Tanjung. (2010). "Development of Islam in Riau", tanjungpinangarticle.blogspot.com, (06-17-2010), http://tanjungpinangarticle.blogspot.com/2010/06/perkembangan-islam-di-riau.html, accessed July 11, 2019.
} 
c. The caliphate of Sulaiman bi Malik sent 35 fleets to the Sabak estuary in Jambi. This fleet is said to depart from Ceylon to Palembang $717 \mathrm{M}$ before going to China.

d. Arab traders have traded in the Malay Realm before Islam entered. Because they have embraced Islam, Islam began to enter the Malay Realm. Most of the traders from Yama, Hadramaut and Oman, Yemeni Islamiers for the efforts of Ali bin Abi Talib had implications for the Islamization of the Malay Realm because they were the ones who spread Islam when stopped at Alam Melayu. ${ }^{13}$

e. Evidence of the historical record of the Islamization of kings in the Malay Realm carried out by preachers from the Middle East. For example Maharaja Drebar II who ruled Kedah in 1136 AD had converted to Islam from S. Abdullah bin S. Ahmad from Yemen using the name Beru Sultan Muzafar Shah. Parameswara also converted to Islam from Sheikh Abdul Azis from Jeddah and changed his name to Sultan Muhammad Syah. ${ }^{14}$

f. Islam has arrived since the first Hijrah (7th century AD) in the form of an Islamic settlement in northern Sumatra known as Ta-Shih.

g. 7) Use of widespread jawi writings. ${ }^{15}$

h. Middle East influences in Qur'an reading.

i. Arabic influences in Malay language such as Books, Letters, Paper, etc. Likewise with the name of the Malay people who have an affinity in Arabic.

j. Available in Malay Nature, Arab descendants are Syed and Syarifah. ${ }^{16}$

From the three theories above, it can be concluded that in fact Islam has come to the Land of Malays since the 7th century AD. However, it has only developed rapidly since the $11-15 \mathrm{M}$ century, namely since the establishment of the Islamic Empire in Malay land which has an important role in the spread of

\footnotetext{
13Jevuska. (2012). "The Process of Entering Islam into Riau", www.jevuska.com, (04-05-2012), http://www.jevuska.com/2012/05/04/proses-including-islam-ke-riau/, accessed July 11, 2019.

14Jevuska. (2012). "The Process of Entering Islam into Riau".

${ }^{15}$ Malay Arabic Writing

${ }^{16}$ Safitri, Mustika., Nuraini Asyidah Urpiah, Siti Amanah, Tri Wijayanti and Fikri Aulia. (2014). "Spreading Islam in Riau"; Jevuska. (2012). "The Process of Entering Islam into Riau".
} 
Islam to all corners of the Malay Archipelago. ${ }^{17}$ Among the ruling Islamic kingdoms in Riau is kesulthanan johor-Riau ${ }^{18}$ and Riau Lingga. ${ }^{19}$

\section{History of Islamic Law in Bumi Melayu Lancang Kuning Riau-Kepri.}

Riau as well as other regions in the archipelago at first was also under the influence of Hindu-Buddhism, especially Buddhism had played an important role during the Srivijaya Kingdom. The entry of Islam in the Riau region, especially in Sia, is thought to have originated from Melaka who embraced the Shafi'i school. ${ }^{20}$

The transformation of the flow of Islamic belief made the Malay people more convinced of their new religion, especially when it was coupled with power, namely the establishment of empires and mysticism, such as Kesulthanan Johor-Riau and Riau Lingga in the 15 th century precisely in AD $15 .^{21}$ This Kesulthanan was led by 16 sulthans, namely from 1528-1819 AD And in 1772 kesulthanan Johor-Riau continued with the success of Riau Lingga until 1911 AD. ${ }^{22}$

During Riau Lingga's death, Islamic law was very strong, as evidenced by the Qur'anic oath by Sulthan Sulaiman Badrul Alamsyah, a tradition of two nahkoda namely Dipertua Muda or the prime minister who came from Bugis and Sulthan Malayas who were in the Middle Ages. ${ }^{23}$

In carrying out the wheels of government in this case, the Elder was assisted by advisors, clerks, qadhi, syah Bandar and several other helpers. During this time several ulama appeared in Riau Lingga, among them Haji ja'far bin Encik Abu bakar alumni Makkah chair of the Rehab of the Clab, he was in the same class as Hasyim As'ari, the founder of NU in Java. ${ }^{24}$

${ }^{17}$ What is called the Arab civilization melayau, which consists of seven branches. The seven branches of Islamic civilization in full are Arab Islamic civilization, Persian Islam, Turkish Islam, Black African Islam, Islamic Continent of India, Islamic Malay Children, and Chinese Islam.

${ }^{18}$ Melayu online.com and Helmaiti. (2011). History of Islamic Asia. Pekanbaru: Pnerbit Nusa Media / Zanafa Publising, cet.I, p. 72

${ }^{19}$ Helmaiti. (2011). History of Islam in Asia Tewnggara, p. 72-90

${ }^{20}$ Mukmin, Mohd. Jamil. (2014). Melaka Center for Spreading Islam in the Archipelago. Kuala Lumpur: Nurin Enterprise, p. 12

${ }^{21}$ Helmaiti. (2011). History of Islam in Asia Tewnggara, p. 72-90

${ }^{22}$ Helmaiti. (2011). History of Islam in Asia Tewnggara, p. 74-85.

${ }^{23}$ Hajj, Raja Ali. (2013). Bugis Malay Lineage. Kuala Lumpur: Library between, p. 67-68.

${ }^{24}$ Helmaiti. (2011). History of Islam in Asia Tewnggara, p. 89. 
The development of Islamic law is also marked by the birth of the works of scholars from the Malay Malay nation. Sheikh Ahmad Lingga Ulama from RiauLingga who produced several of these essays, his full name is Sheikh Ahmad bin Muhammad Yunus Lingga. One of his essays is about the hadith which he gave the title Nashihatu Ahlil Wafa 'ala Washiyatil Mushthafa, which was completed in Mecca, Saturday, 11 Shawwal 1312 H / 1895 AD Malay language. ${ }^{25}$

The birth of classical texts written by the clerics is the manuscript of the samarat muhimmah, the poem by Aninim and the tale of tengkurak koriang by Imam Abdus Salam. ${ }^{26}$

Samarat Muhimmah's manuscript written by Raja Ali Haji contains the concepts of politics and kesulthanan, Dynamics of thought towards the concepts of the meaning of "king" and "kingdom". Based on Malay texts, TS, BC, and BS, the rantau Muslim rulers of Malay not only used the title of sultan, but also claimed to be the shadow of Allah on earth (Zhill Allah fi I-ard), or the shadow of Allah in the world (Zhill Allah fi 1-alam). While in the text of the TSM no such title was found, even feeling worried could bring polytheism. In this text also stated, the power legitimized by such titles allows tyrants to apply. ${ }^{27}$

This dynamic of thought occurred because the author influenced the sociocultural background and responsibilities which he carried on his shoulder as a royal legal advisor. Previous Malay text-text shows a description of the concept of the king and the kingdom "more" familiar with the concept of Sufism, even influenced by pre-Islamic concepts. While TsM is more "close" to the meaning of the concept of fiqh (sharia oriented). ${ }^{28}$

Sultan (king) is just an ordinary human being, like other humans whose legitimacy is not caused because he has special relationships with the supernatural nature that no one else has. Therefore, even though in many places the TSM emphasizes obedience to the king and the prohibition on "disobedience" to him, but

\footnotetext{
${ }^{25}$ Utusan. (2009). "Malaysian Envoy to Speak Religion", ww1.utus.com.my, http:/ /ww1.utus.com.my/utus/info.asp?y=2009\&dt=0309\&pub=Utusan_Malaysia\&sec=Bicara_Aga ma\&pg=ba_01.htm\#ixzz3J6IFyGPS C Messenger Melayu (M) Bhd, accessed July 11, 2019.. p. 207-250.

${ }^{26}$ As'ari LA, Zul. (2010). Classical Islamic Manuscript of Rian Region. Pekanbaru: UIN Suska Riau,

${ }^{27}$ Mahdini. (2010). Political Ethics of Raja Ali Haji's View in Tsamarat al-Mubimmah. Pekanbaru: Pusaka Riau Foundation, p. 43-44.

${ }^{28}$ Mahdini. (2010). Political Ethics Views of Raja Ali Haji, p. 43-44
} 
explained that the basis of obedience is loyalty to the Shari'ah teachings and commitment to the benefit of the Muslims. The meaning of the concept of "lawlessness" like this is different from other Malay texts, such as the text TS, BC, and BS which shows the absolute loyalty of the people to the king, without limits. ${ }^{29}$

As for the meaning of the kingdom, it is not only used to show the power inherent in a ruling king, but it can be felt that there is a concept of the state. For example, the phrase "becomes our king in the kingdom of this country with all its subdued regions". There is the term "royal office" which means a position in a government, such as vizier, Islamic sheikh, minister, qadi al-qudah, amir, kadi, katib, (clerk), and others. While in other Malay texts such as BS, it does not see royal institution as an abstract concept separate from the ruler or a set of powers inherently in the position of the ruler. In such a situation the people are more following and more loyal to the king's person than to abstract ideas (ideals) that are separate from the ruler. In accordance with the objectives to be achieved in the administration of the kingdom, the law of establishing a kingdom is "fardu kifayah". The purpose of the kingdom presented by the Minister of Religion was actually closer to understanding the achievement of the principle of justice in this modern era. The principle of justice is related to fairness and legal certainty, treatment and sharing of results, a balanced sense of life. All of them are summarized in the implementation of order, seeking welfare, defense and upholding justice through judicial bodies. ${ }^{30}$

Whereas the poem which consists of 240 stanzas, contains the life of the Rasulllah with the companions and togetherness of friends accompanying the Apostle when Hijrah was successful in the city of Medina because it had united the Muhajirin and Ansar became the brotherhood of the afterlife. ${ }^{31}$

Furthermore, the saga of tengkurak koriang by Imam Abdus Salam, tells the story of Prophet Isa and the other Prophets and their miracles. It teaches the people

${ }^{29}$ Mahdini. (2010). Political Ethics Views of Raja Ali Haji, p. 37-39

${ }^{30}$ Mahdini. (2010). Political Ethics Views of Raja Ali Haji, p. 47-59

${ }^{31}$ As'ari LA, Zul. (2010). Classic Islamic text of Rian Region, p. 234-244. 
the determination and the strength of the faith and understands the duties and obligations of a servant to the uncle. ${ }^{32}$

From the few paragraphs above, it can be concluded that the history of Islamic law on Malay earth is very flexible in accordance with the situation and condition, because basically the Malay Muslims of Riau who are Shafi'i tend to use Qias and Ijtihad in dealing with all the problems of the ummah. adjust by the culture and national culture of Malay Malay which is very much in line with Islamic teachings and Islamic law itself. This is also the meaning of some historians that Islam and Malay have a tug of war between culture and Islamic Shari'a. ${ }^{33}$

\section{Codification of Islamic Law with Riau Malay Culture in Bumi Lancang Kuning Riau-Kepri.}

The arrival of Islam in this area was welcomed because Islam did not distinguish between human degrees in society. In Islam, human beings are the same as God Almighty, what distinguishes human degrees is their fear. Therefore, the religion of Islam quickly developed in the community and had a big influence on the joint life of the Malay people. Even Islam can influence the identity of Malayness of the people of Riau, namely: a person called "Malay people" is Malay, is Malay and is Muslim, ${ }^{34}$ if there are Malay people adhering to other than the religion of Islam, it is a very big disgrace, so Malay Muslims have a single Malay-Islamic dual philosophy that cannot be separated. ${ }^{35}$

${ }^{32}$ As'ari LA, Zul. (2010). Classic Islamic text of Riau Region, p. 244-245.

${ }^{33}$ Dejavaraditya. (2010). "Overlapping Islam Is Not Islamizing Malay", dejavaraditya.wordpress.com, https://dejavaraditya.wordpress.com/2010/05/29/\%E2\%80\%9Cmemelayukan $\%$ E2\%80\%9D-islambukan- $\%$ E2\% 80\% 9 Islamize \% E2\% 80\% 9D Malay /, accessed 11 July 2019.

${ }^{34}$ Osman, Mohd. Taib. (2009). "Malay Religion and Trust: Organization and Structure", in Mohd. Taib Osman (ed.), Malay Society Structure, Organization and Manifestation. Kuala Lumpur: Language and Library Council, p. 147.

${ }^{35}$ Al-Mudra, Mahyudin. (2008). Malay Redefinition: Efforts to Bridge the Difference in the Concept of the Allied Nations of the Nation. Yogyakarta: Malay Culture Study and Development Center in collaboration with Adicita Karya Nusa, p. 11-12. 
In interacting, Malay people always use Malay and with Malay Arabic writing which is also known as Jawi. There are many Malay words that are adaptations of Arabic, such as: history, manners, death, tendons, tools, denial and so on. ${ }^{36}$

In the economic field, the economic system of the Riau community based on the approach of Anthropology is different from that of Economics. In a modern economic approach emphasis is given to the economic aspects themselves, without violating the values of Islamic Shari'a, while in the approach Anthropology concerns are concentrated on the process of change experienced by humans to achieve the purpose of use and benefit to mutual benefits. Humanitarian aspects are a major factor for Anthropology researchers. However, the relations between the two fields of science are interrelated and cannot be separated, that is what is in the Muslim economic system of Riau. ${ }^{37}$

Malay people are Malay-based, meaning that the prevailing adat is the customs that are buried in syarak. In the Riau region, fara'id law applies (in the distribution of inheritance), which regulates the distribution of inheritance with the patriarchal system in accordance with Islamic teachings. ${ }^{38}$

In the political sphere, the influence of Islam is reflected in the Government structure, namely: an empire based on Islam with the Sultan as the head of Government. Ulama who sit in the Government (Mufti) function as advisors to the Sultan in solving difficult problems in the religious and legal fields which include the law munakahat (marriage), Jinayat (Criminal), Ishlah (Persengkaraan) and Fara'id (Legacy Affairs). ${ }^{39}$

The success of the king in leading his people in the past, made History of Malays imagine the importance of the role of the Malay kings. In essence, which brings and creates "Malay greatness" are Malay kings who bear the image of greatness. The image of the king's greatness is carried on praiseworthy qualities, such

\footnotetext{
${ }^{37}$ Wan Yusof, Wan Abdul Kadir. (2009). "The Economic System of Malays", in Mohd. Taib Osman (ed.), Malay Society Structure, Organization and Manifestation. Kuala Lumpur: Language and Library Council, p. 90.

${ }^{38}$ Wan Yusof, Wan Abdul Kadir. (2009). "The Economic System of Malays", in Mohd. Taib Osman (ed.), Malay Society Structure, Organization and Manifestation.

${ }^{39}$ Wan Yusof, Wan Abdul Kadir. (2009). "The Economic System of Malays", in Mohd. Taib Osman (ed.), Malay Society Structure, Organization and Manifestation, p. 137
} 144.

${ }^{36}$ Hajj, Raja Ali. (1275 H, 1986/1987). Transliteration R. Hamzah Yunus. Pekanbaru, p. 33- 
as being virtuous, being fair, generous, wise towards his people and having high spiritual knowledge as played by Sang Sapurba. ${ }^{40}$

Sang Sapurba held a kind of 'contract' or 'initial agreement' with the people represented by Demang Lebar Daun, had gotten 'sovereign' or his power to become king. This contract is a guarantee of agreement all the time about how the ruler, namely Sang Sapurba acts on his people or vice versa. ${ }^{41}$ From the contract, the concept of the origin of the ruler was born which was seen mystically and purely as having reduced the concept of sovereignty and derhaka. Daulat in Malay political language is simply formulated as 'high' and 'big' powers and powers, including birth and mind, which at any time develop. Thus the sovereignty is the power of the king's absolute power which comes from the sacred quality of the king with supernatural powers which guard him and with the immortality of his power. The concept of sovereignty is usually associated with the king's power and control of the nonmaterial world. Sovereign ownership is the absolute right of the king to be obtained from birth, which cannot be taken away. ${ }^{42}$

The concept of the sovereign rulers developed in harmony with the concept of derhaka, which is an important term in Malay political language. The word derhaka is not from Arabic, Persian or Turkish, it is entirely a local term. Borrowing the understanding developed by Omar, ${ }^{43}$ derhaka means pengianhaanan to God, ruler or sultanate. Peng'hianat'an which emerged from this understanding took the khiyanah Arabic word, which by the Malay-Indonesian dialect is called hianat or khiyanat, so actually the essence of derhaka is nothing but hianat. Thus, even though the term derhaka comes from a local language, the conceptual implications are fully filled with Islamic concepts and values.

Moreover, the Riau sultanate, both the Riau-Lingga Kingdom and the Siak Kingdom, were a continuation (inheritance) of the traditions of the Melaka-Johor

${ }^{40}$ Mahdini. (2010). Political Ethics Views of Raja Ali Haji, p. 8.

${ }^{41}$ Hasbullah. (2014). "Islam in the Frame of Local Culture (Study of the Integration of Islam in Riau Malay Culture)". Faculty of Ushuluddin Uin Suska Riau, Tolerance: Bergama Community Communication Media, Vol.6, No.1, p. 10

${ }^{42}$ Mahdini. (2010). Political Ethics Views of Raja Ali Haji, p. 10. 223.

${ }^{43}$ Omar, Arifin. (2013). Malay Nation: Malay Concept of Democracy and Community. Singapore, p. 
Sultanate. Even the Sultan of Siak had blood relations with the Sultan of Melaka, and Siak at that time was clearly under the rule of Melaka. ${ }^{44}$

The entry of Islam in the Siak area did not only replace their previous religion, but gradually affected the Siak Malay culture or Riau in general as a whole. In Yusmar Yusuf's view, almost all the patterns of life of Malays have been colored by Islam. From this the emergence of the view that "Islam is synonymous with Malay". ${ }^{45}$

The pattern of governance or leadership in Malay society (especially the Siak Kingdom) already contained democratic values, because the king's power was not too absolute, but limited, this could be seen from the government structure of the Siak Kingdom during the reign of Sultan Syarif Hasyim based on Bab al-Qawa'id which means the 'door of all handles' both in the center and in the regions as follows: (1) Sultan (king), (2) Council of ministers (royal council), (3) Judges of the police, (4) Sharia judges, (5) Judges chief or hinduk. ${ }^{46}$

In the field of art, the influence of Islam is evident in the zapin dance, tambourine, marhaban, decoration and design of buildings, towers and the tops of mosques as well as paintings characterized by Islam with a message of peace and harmony. ${ }^{47}$

In the design of the house, the influence of Islam is seen in the roofs of Malay homes, whether the kajang roof, folding pandanus, and others are like two palms that are reunited with their fingertips like when upholding deity (worshiping).

${ }^{44}$ Hashim, Muhammad Yusoff. (2002). (organizer), Hikayat Siak. Kuala Lumpur: Language and Culture Council, 1992; Situmorang, T.D. and A. Teeuw. (2002). Malay History. Jakarta: Balai Pustaka; Lutfi, Muchtar., Soewardi MS. and Wan Ghalib, et.al. (editor). (2007). History of Riau. Pekanbaru: Local Government Tk. I Riau ; Ahmad, Abdul Samad. (2006). Sulalat al-Salatin Malay History. Kuala Lumpur: Language and Library Board; Hasbullah. (2014). Islam in the Frame of Local Culture, p. 12

${ }^{45}$ Lutfi, Amir. (2011). Law and Changes in the Power Structure of the Implementation of Islamic Law in the Siak. Malay Sultanate 1901-1942. Pekanbaru: Susqa Press; Al-Attas, S.M. Naquib. (2000). Islam in Malay History and Culture (translation). Bandung: Mizan; Budisantoso, S., Parsudi Suparlan and Ahmad Yunus, et.al. (editor). (2005). Riau Malay Society and Culture. Pekanbaru: Riau Provincial Government I; Abdullah, Taufik and Sharon Siddique (eds.). (2008). Islamic Tradition and Awakening in Southeast Asia. Jakarta: LP3ES; Mutalib, Hussin. (2005). Islamic Ethnicity of the Malay Political Perspective (translation). Jakarta: LP3ES; Muzani, Syaiful (ed.). (2003). Development and Awakening of Islam in Southeast Asia. Jakarta: LP3ES; Hasbullah. (2014). Islam in the Frame of Local Culture, p. 12.

${ }^{46}$ Yunus, Hasan (literacy). (2010). Bab al-Qawa'id. Pekanbaru: Riau Heritage Foundation; Hasbullah. (2014). Islam in the Frame of Local Culture, p. 11.

${ }^{47}$ Diery. (2012). "History of Riau Province", diery-community.blogspot.co.id, (08-08-2012), http://diery-community.blogspot.co.id/2012/08/sejarah-provinsi-riau.html, accessed July 11, 2019. 
The essence is, that we as spirits who live in this world should always remember Allah and give thanks to Him. ${ }^{48}$

\section{Compilation of Islamic Law in Bumi Melayu Lancang Kuning Riau-Kepri.}

\section{Melayu Lingga Raja Ali Haji}

In the Malay realm, since the founding of the Johor-Riau-Lingga Kingdom there has also been a judicial institution that uses the view of the legal system of syarak (sharia) which continues to uphold local customary law. The purpose of the judiciary was to apply the law (Islamic criminal) to the creation of justice at the time of the Johor-Riau-Lingga Kingdom.

Tsamarat Al Muhimmah, is a book of the hands of Raja Ali Haji, a scholar of the L800an era, about the judiciary and the state system. It is Drs Mahdini. MA, a contemporary era scholar who rewrites and reviews the thoughts of Raja Ali Haji specifically the problem of the justice system. Tsamarat AI Muhlmmah was studied in depth by Mahdini, then the work was published in 1999 by the Pusaka Riau Foundation under the title Tsamarat AI-Muhimmah, Thought of the King All Hajj About the Judiciary. The book contains two main parts, one concluding section and two sections on how the background of the text of Ash Tsamarat Al Muhimmah by Raja Ah Haji. The procedure for impeachment and dismissal of kings and royal officials is explained in the first part of Mahdini's book. ${ }^{49}$

All administrative and legal mechanisms of the kingdom are based on the legal principles of sharak and customary law. In terms of the appointment of the king, it is carried out in three ways First, through the election of the Ahlul Hali wal Aqdl body, the second through the appointment by his predecessor, is called istikhlaf. Third through taking or seizing power. ${ }^{50}$

${ }^{48}$ Effendi, Tenas. (1981). Riau Malay History. Pekanbaru, p. 78; Byuox. (2015). "History of Malay Riau, land and sea", byuonx.blogspot.co.id, (03-04-2015), http://byuonx.blogspot.co.id/2015/03/sejarah-melayu-riau-daratan-dan -link.html, accessed July 11, 2019.

${ }^{49}$ Mahdini. (2010). Tsarnarat Al Mubimrnah, Thought of King Ai Hajj About Justice. Penerbit Yayasan Pusaka Ria, p. 1.

${ }^{50}$ Mahdini. (2010). Tsarnarat Al Mubimrnah, p. 3 
The second chapter, discusses Kingdom Order and Court Rules or the structure of state institutions and judicial bodies. Judicial institutions are placed as the main condition of a country. Because of the strategic role of this institution, there must be rules and regulations regarding the way the institution operates. So the issue of the code of ethics of the judiciary and all kinds of conditions applied in a judicial institution is explained specifically and in detail. Raja Ahi Haji through Tsamarat Al Muhimmah presents the issues of detailed judicial rules which address: the meaning of the judiciary, the requirements to become qadil, and the procedure for carrying out cases in the court. Mahdini did not miss discussing the ideal authority and judicial structure in the view of Raja Ahi Hajj. The ideal structure consists of two layers, namely the small court located at the regional level led by the Qadli and the court of justice in the capital city, led by the Qadli al Qudlah. ${ }^{51}$

Although vital, the role of the judicial institution is not independent and religious institutions. The uhama were put down to help smooth the work of the qadli. Whereas Shaykh al-Islam or the head of state is responsible for the continuation of a fair process of justice. In addition to issuing fatwas, Syekh al Islam also carried out the mandate to supervise judicial institutions. ${ }^{52}$

While the implementation of state duties was carried out by Wazir alAdhim, the main aide of Shaykh al-Islam. This Vizier is fully responsible for implementing the wheels of government. The judiciary is under the supervision of Syekh Al Islam due to the function of the court (the court) as "the place to establish the law for all servants of Allah Ta'ala ${ }^{.53}$

According to Mahdini's interpretation, the Tsamarat trial court was held based on legal proceedings commonly used in Islamic court jurisdiction, the Jinayah, Mu'amalah and Munakahat fields. The qadli that is appointed reflect the mastery of each of these areas of law, because there are special qadli that deal with who, jinayah and mu'amalah. Qadli was appointed in his position as qadli al

${ }^{51}$ Mahdini. (2010). Tsarnarat Al Mubimrnah, p. 136.

52Mahdini. (2010). Tsarnarat Al Mubimrnah, p. 135.

${ }^{53}$ Mahdini. (2010). Tsarnarat Al Mubimrnah, p. 118. 
qudah (minister of justice). The qadli are responsible for resolving legal issues that are submitted to him. So it is not a judge who decides the case. ${ }^{54}$

The workings of the judiciary and the state system presented by the King All Hajj in Tsamarat Al Muhimmah are influenced by classical Islamic works such as Ihya ulumuddin (al Ghazali) and Al Ahkam al Sulthaniyah (Al Mawardi's works) and several other hipograms.

Indeed, the text of Tsamarat $\mathrm{Al}$ Muhimmah focuses on the state and basic framework of state institutions under the king. Because of the function and position of King All Haji as a cleric and religious adviser to the Kingdom of Riau Lingga, then Raja Ali Haji has an interest in spawning state rules that underlie Islamic law. ${ }^{55}$

Tsamarat's work is aimed at the king, the great emperors and general law enforcement officers (qadli). To enforce justice, Tsamarat, according to Mahdini, distinguishes the terms "judge" and "qadli". Qadli is used to express the authority of the person who decides on a matter based on God's law. The term "judge" is used to state that the person in charge of helping the vizier (world affairs minister) runs the government and does not handle legal matters. ${ }^{56}$

\section{Babul Al-Qawaid Book of Law Judgment of the Kingdom of Siak}

Babul Qawa'id is a law book in the Siak Sri Indrapura Sultanate written by Tengku Putera (Ngah) Said Hasyim with the title Sultan Assyaidis Syarif Hasirn Abdul Jalil Syarifuddin. This 90-page book describes the laws imposed on Malays and other nations related to Malays. In the book Siak Sri Indrapura (2005) it is explained that the first part of Babu! Qawa'id is an opening section consisting of two chapters and describes the motivation, background, name and manuscript, and states that the contents do not give me law for non-Malays or Malays who are employees of the Netherlands Indies Government, except those who are involved with Malay people. The court for this case will involve officials

${ }^{54}$ Mahdini. (2010). Tsarnarat Al Mubimrnah, p. 118

${ }^{55}$ Mahdini. (2010). Tsarnarat Al Mubimrnah, p. 119.

${ }^{56}$ Mahdini. (2010). Tsarnarat Al Mubimrnah, p. 163. 
of the Siak Sri Indrapura Sultanate and officials of the Dutch East Indies Government. $^{57}$

The High Court is in the capital city of the Kingdom called the Qodhi Density which is chaired by the Sultan, while the Member judges are datuk-datuk from each tribe, Qodhi and Controleur namely:
a. Datuk Sri Pekermaja (Head of Flat Land)
b. Datuk Sri Bijuangsa (Tribal Chief of Fifty)
c. Datuk Sri Dewaraja (Coastal Chief)
d. Datuk Amir Pahlawan (Kampar Chief)
e. Qodhi
f. Controleur

Qodhi Density Hall is named Balairung, which is the place where judicial activities are held, which deal with religious matters such as Muamalat (civil) and Jinayat (criminal) in the form of Jarimah such as Hudud, Qisas Diat and Ta'zir. ${ }^{58}$

The main section of Babul Qawa'id consists of 22 chapters which cover 154 articles. The first chapter details the division of the state into 10 provinces and their boundaries. Furthermore, the written chapters are also arranged, among others:
a. Title of the Ruling at Tenseng Density,
b. The Amount of Sentences to be Trialed at High Density,
c. Cases that will be held before a police judge,
d. Duties of Sultanate and Colony Province Judges,
e. Tribal names. ${ }^{59}$

Besides Babul Qawa'id, changes in the government system were also seen in government institutions in the Sultanate of Siak Sri Indrapura. In the book A History of the Kingdom of Siak Sri Indrapura and Its Heritage $(1999 / 2000)$, it is stated that in running the government, the sultan is assisted by

\footnotetext{
${ }^{57}$ Suwarno, Swardila, et.al. (2005). Siak Sri Indrapura. Jakarta: Amanah-Lontar, p.88

${ }^{58}$ Suwarno, Swardila, et.al. (2005). Siak Sri Indrapura, p. 88

${ }^{59}$ Suwarno, Swardila, et.al. (2005). Siak Sri Indrapura, p. 88
} 
sultanate officials who lead the institution, both at the center and in the area consisting of:

a. The Sultan is the head of government, the sovereign holder and the highest administrator.

b. The Council of Ministers (Sultanate Council) in charge of selecting and appointing the sultan. This council is together with the sultan making laws and regulations.

c. Hakir Kerapatan Tingqi who is in charge of the general court. Meanwhile, Balai Kerapatan Tinggi is a place to resolve cases that occur in the people of Siak. Head and High Density are sultans and accompanied by Datuk. Kadi of Siak and Controleur Siak functions as members.

d. Hakirn is the head of government at the provincial level as the deputy sultan. The Siak Sri Indrapura Sultanate region consists and $10^{60}$ province, now 9, i.e.:

1) Siak Province has the title Tengku Besar

2) The Merbau Province Holds the Faithful Rich Person of the Senses

3) The Province of Bukit Batu is held by Admiral Setia Diraja

4) Bangko Province has the title Datuk Dewa Pahlawan

5) Kubu Province has the title Datuk Jaya Perkasa

6) Pekanbaru Province has the title of Syahbandar

7) Tapung Kiri Province has the title Syarif Bendahara

8) The Tapung Kanan Province has the title Datuk Bendahara

9) Two State Commissioners of Prince Wira Negara and Prince Wira Kesuma.

e. Sharia judges which are divided into two, first domiciled in the State of Siak Sri Indrapura with the title Kadi Siak. Tasks and Kadi Siak handle courts regarding inheritance or inheritance and customary law issues. The two are domiciled in the province with the title Imam Jajahan. The task of the colonial priest was to help Kadi Siak.

${ }^{60}$ The tenth is the Tebing Tinggi Province with the title Tengku Temenggong Muda. 
f. Hakirn Head of Tribe / Hinduk is the lowest government according to the Siak Sri Indrapura Sultanate hierarchy. Tribal Chief Judge / Hinduk has the gas to carry out the government and regulate the life of the community, religion, and sultanate of their respective tribes. The Chief Judge / Hinduk is subject to the Policy Judge. Province. ${ }^{61}$

\section{CONCLUSION}

From the explanation above, the following conclusions can be drawn:

1. History of the Entry of Islam into Riau Bumi Lancing Kuning Riau Kepri put forward the theory of Arab land.

2. Islamic law in Lancang Kuning Riau-Riau Islands Riau Islands developed in accordance with cultural culture which is indeed commensurate with the teachings of Islam itself.

3. The Codification Process of Islamic Law with Riau Malay Culture on Lancang Kuning Earth is a natural process in accordance with the social cultural values of the Malay Malay nation's own faith, so that there are no obstacles, even though there are still people who believe in the occult nation.

4. Riau Malay Muslims in Implementing the Compilation of Islamic Law in Lancang Kuning Earth are very supportive, because they are familiar with Malay Malay cultural customs identical to Islam.

\section{BIBLIOGRAPHY}

Abdullah, Taufik and Sharon Siddique (eds.). (2008). Islamic Tradition and Awakening in Southeast Asia. Jakarta: LP3ES.

Ahmad, Abdul Samad. (2006). Sulalat al-Salatin Malay History. Kuala Lumpur: Language and Library Board.

Al-Attas, S.M. Naquib. (2000). Islam in Malay History and Culture (translation). Bandung: Miza

Al-Mudra, Mahyudin. (2008). Malay Redefinition: Efforts to Bridge the Difference in the Concept of the Allied Nations of the Nation. Yogyakarta: Malay Culture Study and Development Center in collaboration with Adicita Karya Nusa.

${ }^{61}$ Dewi, Norma, et .al. (2000). A Glimpse of the History of the Kingdom of Siak Sri Indrapura and its Heritage. Bapeda Riau p. 7-8 
As'ari LA, Zul. (2010). Classical Islamic Manuscript of Riau Region. Pekanbaru: UIN Suska Riau.

Bertahta, Raja Tak . (2015). "History of Riau Malay Mainland and the Ocean", byuonx.blogspot.co.id, http://byuonx.blogspot.co.id/2015/03/sejarah-melayu-riau-daratan-dan link.html, accessed July 11, 2019.

Budisantoso, S., Parsudi Suparlan and Ahmad Yunus, et.al. (editor). (2005). Riau Malay Society and Culture. Pekanbaru: Riau Provincial Government I.

Byuox. (2015). "History of Malay Riau, land and sea", byuonx.blogspot.co.id, (03-042015), http://byuonx.blogspot.co.id/2015/03/sejarah-melayu-riau-daratandan -link.html, accessed July 11, 2019.

Dejavaraditya. (2010). "Overlapping Islam Is Not Islamizing Malay", dejavaraditya.wordpress.com,

https://dejavaraditya.wordpress.com/2010/05/29/\%E2\%80\%9Cmemelayu kan $\%$ E2\%80\%9D-islam-bukan-\%E2\% $\quad 80 \% \quad 9 \quad$ Islamize $\% \quad$ E2\% $\quad 80 \% \quad 9 \mathrm{D}$ Malay /, accessed 11 July 2019.

Dewi, Norma, et .al. (2000). A Glimpse of the History of the Kingdom of Siak Sri Indrapura and its Heritage. Bapeda Riau.

Diery. (2012). "History of Riau Province", diery-community.blogspot.co.id, (08-08-2012), http:/ / diery-community.blogspot.co.id/2012/08/sejarah-provinsi-riau.html, accessed July 11, 2019.

Divine, Afdhal. (2013). "Early Entry of Islam into Riau", afdhalilabi.blogspot.com, (1203-2013), http://afdhalilahi.blogspot.com/2013/03/awal-masuknya-islamke-riau.html, accessed 11 July 2019.

Effendi, Tenas. (1981). Riau Malay History. Pekanbaru.

Ferrand, Gabriel. (1922). “L'Empire Sumatranais de Crivijaya, Imprimerie Nationale, Paris", "Textes Chinois".

Hajj, Raja Ali. (1275 H, 1986/1987). Transliteration R. Hamzah Yunus. Pekanbaru.

Hajj, Raja Ali. (2013). Bugis Malay Lineage. Kuala Lumpur: Library between.

Hasbullah. (2014). "Islam in the Frame of Local Culture (Study of the Integration of Islam in Riau Malay Culture)". Faculty of Ushuluddin Uin Suska Riau, Tolerance: Bergama Community Communication Media, Vol.6, No.1.

Hashim, Muhammad Yusoff. (2002). (organizer), Hikayat Siak. Kuala Lumpur: Language and Culture Council, 1992.

Helmaiti. (2011). History of Islamic Asia. Pekanbaru: Pnerbit Nusa Media / Zanafa Publising, cet.I.

Jevuska. (2012). "The Process of Entering Islam into Riau", www.jevuska.com, (04-052012), http://www.jevuska.com/2012/05/04/proses-including-islam-keriau/, accessed July 11, 2019. 
Kadir, Abdul. (2010). History of the Entry of Islam in Riau. Pekanbaru: Indonesian National Library.

Lutfi, Amir. (2011). Law and Changes in the Power Structure of the Implementation of Islamic Law in the Siak Malay Sultanate 1901-1942. Pekanbaru: Susqa Press.

Lutfi, Muchtar, Soewardi MS and Wan Ghalib, et.al. (Editor). (2011). History of Riau. Pekanbaru: Local Government Tk. I Riau.

Lutfi, Muchtar., Soewardi MS. and Wan Ghalib, et.al. (editor). (2007). History of Riau. Pekanbaru: Local Government Tk. I Riau.

Mahdini. (2010). Political Ethics of Raja Ali Haji's View in Tsamarat al-Mubimmah. Pekanbaru: Pusaka Riau Foundation.

Mahdini. (2010). Tsarnarat Al Mubimrnah, Thought of King Ai Hajj About Justice. Penerbit Yayasan Pusaka Ria.

Mukmin, Mohd. Jamil. (2014). Melaka Center for Spreading Islam in the Archipelago. Kuala Lumpur: Nurin Enterprise.

Mutalib, Hussin. (2005). Islamic Ethnicity of the Malay Political Perspective (translation). Jakarta: LP3ES.

Muzani, Syaiful (ed.). (2003). Development and Awakening of Islam in Southeast Asia. Jakarta: LP3ES.

Omar, Arifin. (2013). Malay Nation: Malay Concept of Democracy and Community. Singapore.

Osman, Mohd. Taib. (2009). "Malay Religion and Trust: Organization and Structure", in Mohd. Taib Osman (ed.), Malay Society Structure, Organization and Manifestation. Kuala Lumpur: Language and Library Council.

Perlis. (2019). "Islam in the Malay Realm", wmw.perlis.uitm.edu.my, http://www.perlis.uitm.edu.my/cituimages/stories/gallery202\%20\%20islam \%20di\%20alam\%20melayu\%20\%5Bpp \% 5D.pdf, accessed July 11, 2019.

Pinang, Tanjung. (2010). "Development of Islam in Riau", tanjungpinangarticle.blogspot.com, (06-17-2010), http:/ / tanjungpinangarticle.blogspot.com/2010/06/perkembangan-islam-diriau.html, accessed July 11, 2019.

Safitri, Mustika., Nuraini Asyidah Urpiah, Siti Amanah, Tri Wijayanti and Fikri Aulia. (2014). "The spread of Islam in Riau", a paper on the history of Southeast Asian Islam, the Miftahul 'Ulum Tanjungpinang Islamic College, document. Tips, http://dokumen.tips/documents/makalah-penyebaran-islam-diriau.html, accessed July 11, 2019.

Situmorang, T.D. and A. Teeuw. (2002). Malay History. Jakarta: Balai Pustaka Sunanto, Musyrifah. (2015). History of Indonesian Islamic Civilization. Jakarta: PT Raja Grafindo Persada.

Suwarno, Swardila, et.al. (2005). Siak Sri Indrapura. Jakarta: Amanah-Lontar.

Utusan. (2009). "Malaysian Envoy to Speak Religion", ww1.utus.com.my, http:/ /ww1.utus.com.my/utus/info.asp?y=2009\&dt=0309\&pub=Utusan_M 
alaysia\&sec $=$ Bicara_Agama\&pg=ba_01.htm\#ixzz3J6IFyGPS (C) Messenger Melayu (M) Bhd, accessed July 11, 2019..

Wan Yusof, Wan Abdul Kadir. (2009). "The Economic System of Malays", in Mohd. Taib Osman (ed.), Malay Society Structure, Organization and Manifestation. Kuala Lumpur: Language and Library Council.

Wikipedia. (2019). "Malay Riau", wikipedia.org, http://id.wikipedia.org/wiki/Melayu_Riau, accessed July 11, 2019.

Yhiiie. (2012). "History of the Entry of Islam in Riau", Ybiiie.Wordpress.Com, (11-292012), https://yhiiie.wordpress.com/2012/11/29/sejarah-masuknya-islamdi-riau/, accessed July 11, 2019.

Yunus, Hasan (literacy). (2010). Bab al-Qawa'id. Pekanbaru: Riau Heritage Foundation. 